ISSN 1994-7836 (print)

ISSN 2519-2477 (online)

УДК 631.95.(478)

Article info

Received 05.02.2017 p

Інститут агроекології і природокористування НААН Украӥни, м. Київ, Україна

\title{
ОСОБЛИВОСТІ ЕКОЛОГО-ЕКОНОМІЧНИХ СИСТЕМ ТРАНСКОРДОННОГО СПІВРОБІТНИЦТВА КАРПАТСЬКОГО РЕГІОНУ
}

\begin{abstract}
Обгрунтовано пріоритетні особливості транскордонного співробітництва Карпатського регіону. Звернено увагу на актуальність дослідження транскордонного співробітництва. Проаналізовано прикордонні регіони транскордонного співробітництва Карпатського регіону. Визначено напрями екологоекономічних основ збалансованого природокористування. Запропоновано функціонально-структурну схему еколого-економічних систем транскордонного співробітництва. Екологічна ситуація показує, що для більшої частини Карпатського регіону характерними є істотна антропогенна трансформованість ландшафтів і значна забрудненість навколишнього природного середовищА. В окремих прикарпатських областях сформувалися стабільні території загрозливого екологічного стану. Актуальними аспектами є відповідна теоретико-методологічна розробка та належна практична реалізація транскордонного еколого-економічного співробітництва Карпатського регіону, які відповідали б вимогам Європейських стандартів. Пріоритетними особливостями здійснення збалансованого природокористування є ті, що пов'язані зі створенням цілісного еколого-економічного механізму та інституціонального забезпечення.

Ключові слова: природні ресурси; навколишне природне середовище; сільське господарство; раціональне природокористування.
\end{abstract}

Вступ. Дослідження транскордонного співробітництва завжди були і залишаються актуальними проблемами екологічної економіки. Враховуючи те, що європейський вектор зовнішньої політики України, зокрема співробітництво та вступ до Європейського Союзу (СС) $\epsilon$ пріоритетними, то сьогодні в Україні потрібно розробити таку теоретико-методологічну основу й відповідні практичні заходи, які забезпечили б позитивні зрушення євроінтеграційного вектора розвитку в Україні. Саме тому особливо важливими й актуальними аспектами в цьому напрямі $\epsilon$ відповідна теоретико-методологічна розробка та належна практична реалізація транскордонного еколого-економічного співробітництва Карпатського регіону, які відповідали б вимогам СС.

Постановка завдання. Основною метою цієї роботи $€$ визначення оптимізації транскордонного співробітництва Карпатського регіону.

Аналіз останніх досліджень і публікацій. Проблеми формування механізмів транскордонного співробітництва, визначення еколого-економічної ефективності їх функціонування і зв'язків із рівнем соціально-економічного розвитку досліджено у працях вітчизняних і зарубіжних науковців: О. Ф. Балацького, І. К. Бистрякова, Б. В. Буркинського, О. О. Веклич, І. М. Грабинського, Л. С. Гринів, Б. М. Данилишина, М. І. Долішнього та ін. Однак теоретико-методичні дослідження у зазначеному напрямі не повною мірою розкривають проблему еколого-орієнтованого регіонального розвитку і транскордонного співробітництва.

Проблематику розвитку транскордонних регіонів висвітлено у багатьох роботах вітчизняних вчених, таких як В. І. Пила, О.А.Гарасюк, Т. В. Терещенко, Н. А. Мікула, І. П. Нагорна та ін. (Nahorna, 2007; Pyla et al. 2006), де досить детально та змістовно розглянуто проблеми транскордонного розвитку регіонів, однак цей аспект еколого-економічного життя країни перебуває у процесі постійного розвитку та змін, тому потре- бує постійної уваги та аналізу.

Виклад основного матеріалу дослідження. Вивчення еколого-економічних чинників у прикордонних регіонах України та сусідніх держав СС набуває особливого значення, оскільки європейський вектор зовнішньої політики України, зокрема співробітництво та вступ до ЄС, є пріоритетними.

Розвиток транскордонного співробітництва (ТC) $є$ одним із сучасних ефективних напрямів реалізації екологічної політики держави. Чіткий механізм транскордонного співробітництва $є$ потрібною передумовою його дієвості та результативності.

Карпатський єврорегіон став важливим інструментом співробітництва місцевих і регіональних влад України не тільки з окремими державами, але і всього Євросоюзу (Holovach, 2010).

Важливою проблемою Карпатського регіону, що у перспективі може гальмувати розвиток його рекреаційної сфери, є несприятлива екологічна ситуація, яка пов'язана 3 багатьма чинниками: незбалансованістю розвитку 167 окремих галузей економіки та промисловості, неналежним ставленням до природних ресурсів та довкілля та ін. На думку фахівців, все це призвело до інтенсивного природокористування, нераціонального природокористування, погіршення природного навколишнього середовища загалом. Забрудненість середовища безпосередньо залежить від дії забруднювальних джерел та факторів, які негативно впливають на стан здоров'я населення, на показники смертності та дитячої захворюваності (Maniv, Lutskyi \& Maniv, 2006).

Оцінення екологічної ситуації показує, що для більшої частини Карпатського регіону характерними $\epsilon$ icтотна антропогенна трансформованість ландшафтів $\mathrm{i}$ значна забрудненість середовищА. В окремих прикарпатських областях сформувалися стабільні території загрозливого екологічного стану. Останніми роками значно зросла загроза виникнення екологічно небезпеч-

Цитування за ДСТУ: Гадзало А. Я. Особливості еколого-економічних систем транскордонного співробітництва Карпатського регіону / А. Я. Гадзало // Науковий вісник НЛтУ України. Серія економічна. - 2017. - Вип. 27(2). - С. 108-111.

Citation APA: Gadzalo, A. Ya. (2017). SOME FEATURES OF ECOLOGICAL-ECONOMIC SYSTEMS OF TRANSBORDER COOPERATION IN THE CARPATHIAN REGION. Scientific Bulletin of UNFU. Economic Series, 27(2), 108-111. Retrieved from:

http://nv.nltu.edu.ua/index.php/journal/article/view/284 
них техногенних аварій і катастроф. За забрудненістю повітря і вод Карпатський регіон, за даними В. Гобели, посідає четверте, а за забрудненістю грунтів мінеральними добривами і пестицидами - відповідно, перше і друге місця в Україні (Hobela, 2010).

Певне значення для ринкової конвергенції має функціонування "Карпатського Єврорегіону", який уже понад 20 років продовжує відігравати роль організатора i координатора міжрегіонального та транскордонного співробітництва у найрізноманітніших сферах економічного й суспільного життя. Зокрема, саме через інституції "Карпатського Єврорегіону" Закарпатська обл. встановила партнерські зв'язки з низкою регіонів Угорщини, Словаччини, Румунії та Польщі (табл.). 3 деякими із цих регіонів розробляють і реалізують конкретні програми співпраці (Holovach, 2010).

Табл. Прикордонні регіони транскордонного співробітництва Карпатського регіону

\begin{tabular}{|c|c|c|c|c|c|c|}
\hline \multirow{2}{*}{ Країна } & \multirow{2}{*}{ Регіон суміжній /регіон (область) } & \multicolumn{5}{|c|}{ Україна } \\
\cline { 3 - 7 } & & Львівська & Волинська & Закарпатська & Івано-Франківська & Чернівецька \\
\hline Польща & $\begin{array}{c}\text { Пюблінське воєводство } \\
\text { Підкарпатське воєводство }\end{array}$ & $\times$ & $\times$ & $\times$ & - & - \\
\hline Словаччина & Край Кошице та край Прешув & - & - & $\times$ & - & - \\
\hline Угорщина & Саболч-Сатмар- Берег & - & - & $\times$ & - & - \\
\hline Румунія & $\begin{array}{c}\text { Сату-Маре Марамуреш } \\
\text { Сучава Ботошань Тулча }\end{array}$ & - & - & $\times$ & $\times$ & $\times$ \\
\hline
\end{tabular}

У рамках програм сусідства "Україна-СловаччинаУгорщина" фінансуються чотири проекти від Закарпатської обл. на загальну суму 2,75 млн євро, а саме: "Розвиток Берегівської транскордонної польдерної системи в басейні річки Тиса" - 0,72 млн євро, "Чиста вода" - 0,6 млн євро, "Транскордонні можливості розвитку транспортної логістики" - 0,54 млн євро, "Покращення транскордонного автомобільного руху через будівництво об'їзної дороги навколо м. Берегово" 0,9 млн євро. У рамках цієї програми в області спільно 3 угорськими партнерами реалізується 6 проектів. Серед них - створення інформаційно-туристичних центрів у містах Берегово та Ужгород; розроблення та впровадження транскордонної програми медико-соціальної реабілітації на базі обласної дитячої клінічної лікарні; розроблення комплексного українсько-угорського підходу до спільних протипаводкових заходів; дослідження стану використання біомаси у прикордонному регіоні (Holovach, 2010).

Науковці та політичні діячі низки країн Свропейського Союзу, що неодноразово наголошують наявні зразки трансформації економіки регіонів, зокрема їх соціальної сфери, недоцільно механічно переносити на український грунт. Варто зауважити, що і в рамках самого ЄС існують значні відмінності в організації соціальної сфери та особливостях надання соціальних послуг. Навіть система вищої освіти у межах Євросоюзу може бути як тільки безкоштовною, так і платною.

Погіршення якості навколишнього природного середовища та вичерпність значного обсягу природних ресурсів зумовили потребу пошуку нової парадигми розвитку суспільства, відмінної від використання та ставлення до природи. Такою парадигмою стали ідеї екологічно збалансованого економічного розвитку, які було висвітлено на конференції ООН з питань навколишнього природного середовища та розвитку в Ріо-де-Жанейро в 1992 р. (Furdychko, Lavrov \& Konishchuk, 2010).

Питання якості води на сучасному етапі, як наголошують Н. А. Мікула, В. В. Толкованов, є одним 3 пріоритетних напрямів роботи міжнародних організацій, таких як ООН, Всесвітня організація охорони здоров'я та ін. Рада Європи та Європейський Союз у ході реалізації транскордонного співробітництва досягли значних результатів у цій сфері. Прикладом такої роботи є Гельсінська Конвенція про транскордонні водні шляхи та озера 3 міжнародним статусом, яку підписано у 1992 р. Ї̈̈ метою $€$ контроль над рівнем забруднення транскордонних водних шляхів та озер з міжнародним статусом, запобігання їх забрудненню шляхом розвитку співробітництва між сторонами, що підписали Конвенцію (Honta, 2009).

Якщо взяти до прикладу зарубіжний досвід раціоналізації природокористування, то він може бути дуже цінний для України, де сьогодні доводиться визначити реальні напрями виведення іiї 3 еколого-економічної безвиході. Україна не має ні вдосталь часу на власний пошук ефективних регуляторів збалансованого природокористування (надто критичною є екологічна ситуація), ні ресурсів для забезпечення програми боротьби iз забрудненням навколишнього природного середовища, а також і в сільськогосподарських господарствах, ні міцної законодавчо-виконавчої влади, здатної розробляти і безкомпромісно здійснювати національну еколого-економічну політику.

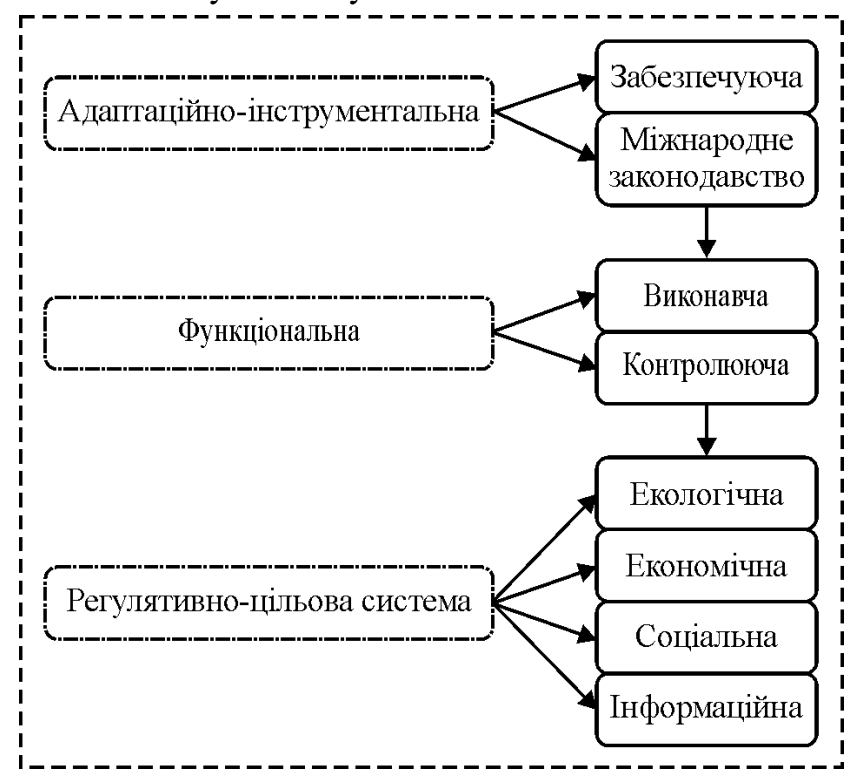

Рис. Функціональна-структурна схема еколого-економічних систем транскордонного співробітництва (авторська розробка)

Екологічна система збалансованого природокористування - це комплекс адаптивних процесів, що дає змогу асимілювати забруднення довкілля та підтримувати природний стан екосистем. 
Це потребує розроблення транскордонної стратегії, що забезпечує виконання таких умов:

- масштаби споживання природно-ресурсного потенціалу не мають перевищувати природних умов регенерації екосистем;

- обсяги промислових та побутових відходів не мають перевищувати асиміляційні можливості біосфери;

- вибір оптимізаційної стратегії має враховувати інтереси як нинішніх, так і майбутніх поколінь.

Економічна система транскордонного співробітництва збалансованого природокористування:

- раціональне та ефективне використання природних ресурсів;

- формування правдивої та гнучкої фіскальної системи;

- формування та використання інструментів механізму для збалансування інтересів серед суб'єктів виробничогосподарської діяльності (див. рисунок).

Для досягнення паритету економічних і екологічних систем структурна перебудова виробництва може слугувати тільки фундаментом реалізації концепції екологічно збалансованого природокористування. Пріоритетні особливості здійснення збалансованого природокористування пов'язані зі створенням цілісного економічного механізму та адекватної інституційної підтримки.

Для вирішення завдань із протидії сучасним викликам транскордонних економічних та екологічних загроз національній безпеці України, серед іншого, потрібно активізувати діяльність ії прикордонних об'єднань. Доцільно, незважаючи на наявні міждержавні проблеми геополітичного, правового чи іншого характеру, активно реалізовувати транскордонне еколого-економічне співробітництво, що дасть змогу вирішити проблеми чи послабити напругу у взаємовідносинах між державамисусідами. I саме на цих напрямах, зокрема із: розв'язання проблем забруднення довкілля; утилізації відходів та створення мережі підприємств з утилізації сміття; підвищення якості питної води та води у річках та озерах; оптимального використання земельних ресурсів; запобігання та подолання негативних наслідків природних та техногенних катастроф. Уже сьогодні можлива організація дієвого транскордонного співробітництва 3 обов'язковим застосуванням методологій екологічної економіки. Реалізація спільних ініціатив 3 визначених питань може зумовити, в подальшому, і активізацію інших сфер транскордонного співробітництва, сприяти

розвитку дружніх і взаємовигідних партнерських відносин між сусідніми державами, забезпечити прозорість державних кордонів, залучення до міжнародного співробітництва на різних рівнях для вирішення наявних еколого-економічних та інших міжнародних проблем.

Висновок. Підсумовуючи, зазначимо, що саме значний потенціал Карпатського регіону, на нашу думку, є провідною передумовою активізації процесів європейської інтеграції на регіональному рівні. Власне, населення регіону, яке формує його інтелектуальний потенціал, є джерелом ділової активності, і забезпечує в сучасних умовах прогресивні тенденції розвитку окремих сфер регіональної економіки. Висока мобільність населення Карпатського регіону, безумовно, також сприяє активізації транскордонного співробітництва та зовнішньоекономічних зв'язків.

3 огляду на це, перспективним напрямом подальших досліджень цієї проблеми має стати виокремлення найбільш вагомих чинників і дієвих механізмів впливу на ефективну зміну формальних та неформальних інститутів суспільства задля цілей досягнення збалансованого природокористування транскордонного співробітництва.

\section{Перелік використаних джерел}

Furdychko, O. I., Lavrov, V. V., \& Konishchuk, V. V. (2010). Ahroekolohichni aspekty okhorony navkolyshnoho seredovyshcha na zasadakh zbalansovanoho rozvytku. Ahroekolohichnyi zhurnal, 2, 5-11. [in Ukrainian]

Hobela, V. V. (2010). Ohliad ekonomichnykh, sotsialnykh ta ekolohichnykh zahroz Karpatskomu rehionu. Scientific Bulletin of $U N$ $F U, 20(13), 81-87$. [in Ukrainian]

Holovach, Yu. V. (2010). Karpatskyi yevrorehion yak forma transkordonnoho spivrobitnytstva Ukrainy z krainamy YeS. Retrived from: http://www.rusnauka.com/15_ AHSN_2010/economics/67853.doc/ htm. [in Ukrainian]

Honta, O. I. (2009). Aktualizatsiia tsilei funktsionuvannia transkordonnoho obiednannia Yevrorehion "Dnipro" na osnovi metodu inhresii. Poliska analityka, 1, 9-13. [in Ukrainian]

Maniv, Z.O., Lutskyi, I. M., \& Maniv, S. Z. (2006). Rehionalna ekonomika. Lviv: Mahnoliia, 638 p. [in Ukrainian]

Nahorna, I. (2007). Transkordonne spivrobitnytstvo yak napriamok yevrointehratsiinykh protsesiv v Ukraini. Teoretychni ta prykladni pytannia derzhavotvorennia, 2, 6-10. Kyiv. [in Ukrainian]

Pyla, V. I., Chmyr, O. S., Harasiuk, O. A., \& Tereshchenko, T. V. (2006). Suchasna rehionalna polityka i transkordonne spivrobitnytstvo. Khmelnytskyi: Vyd-vo KhUUP, 412 p. [in Ukrainian]

А. Я. Гадзало

\section{ОСОБЕННОСТИ ЭКОЛОГО-ЭКОНОМИЧЕСКИХ СИСТЕМ ТРАНСГРАНИЧНОГО СОТРУДНИЧЕСТВА КАРПАТСКОГО РЕГИОНА}

Обоснованы приоритетные особенности трансграничного сотрудничества Карпатского региона. Обращено внимание на актуальность исследования трансграничного сотрудничества. Проанализированы приграничные регионы трансграничного сотрудничества Карпатского региона. Определены направления эколого-экономических основ сбалансированного природопользования. Предложена функционально-структурная схема эколого-экономических систем трансграничного сотрудничества.

Экологическая ситуация показывает, что для большей части Карпатского региона характерны существенная антропогенная трансформированность ландшафтов и значительная загрязненность окружающей среды. В отдельных прикарпатских областях сформировались стабильные территории угрожающего экологического состояния. Актуальными аспектами являются соответствующая теоретико-методологическая разработка и надлежащая практическая реализация трансграничного эколого-экономического сотрудничества Карпатского региона, отвечающих требованиям Европейских стандартов. Приоритетными особенностями осуществления сбалансированного природопользования являются те, которые связаны с созданием целостного экологоэкономического механизма и институционального обеспечения.

Ключевые слова: природные ресурсы; окружающую среду; сельское хозяйство; рациональное природопользование. 
A. Ya. Gadzalo

SOME FEATURES OF ECOLOGICAL-ECONOMIC SYSTEMS OF TRANSBORDER COOPERATION IN THE CARPATHIAN REGION

The European vector of Ukraine's foreign policy, including cooperation and joining the European Union (EU) being a priority, theoretical and methodological basis and appropriate practical implementation of cross-border environmental and economic cooperation of the Carpathian region that meet EU requirements are important aspects nowadays. Therefore, the research aims at determining optimization of cross-border cooperation of the Carpathian region. In course of the study the authors analyzed the features of cross-border cooperation of the Carpathian region. We have identified the directions for ecological and economic foundations of sustainable environmental management. The functionally structural chart of the ecological and economic systems of cross-border cooperation is developed. The study conducted has revealed that the environmental situation shows that most of the Carpathian region is characterized by significant anthropogenic transformation of landscapes and highly polluted environment. In some areas of the Carpathian region the stable areas threatening the environment are formed. Thus, some important aspects are relevant theoretical and methodological development and appropriate practical implementation of cross-border environmental and economic cooperation of the Carpathian region that meet the requirements of European standards. Priority peculiarities to implement sustainable environmental management are those associated with the creation of integrated environmental and economic mechanism and institutional support.

Keywords: environmental and economic principles; natural resources; environment; agriculture; rational environmental management. Інформація про автора:

Гадзало Андрій Ярославович, канд. екон. наук, докторант, Інституту агроекології і природокористування НААН України, м. Київ, Україна. Email: agadzalo@gmail.com 